\title{
Spatial distribution of the Ocypode quadrata (Crustacea: Ocypodidae) along estuarine environments in the Paranaguá Bay Complex, southern Brazil
}

\author{
Leonardo C. da Rosa \& Carlos A. Borzone
}

Centro de Estudo do Mar, Universidade Federal do Paraná. Caixa Postal 50002, 83255-000 Pontal do Paraná, Paraná, Brasil. E-mail: cielcr@furg.br

\begin{abstract}
This study examines the spatial distribution of the ghost crabs, Ocypode quadrata Fabricius, 1787, in thirteen estuarine sandy beaches located along two main axes of the Paranaguá Bay Estuarine Complex, southern Brazil. Burrow densities of ghost crabs were measured at three beach levels established around the high tide mark during the summer and winter of 2005. All beaches showed a steep beach face slope $\left(2.6\right.$ to $\left.8.3^{\circ}\right)$ with sediment composition varying from well sorted fine sand to very poorly sorted coarse sand towards the upper estuary. Water salinity ranged from around 31 at those beaches near the bay inlet, to 14 at beaches in the inner estuary. The burrow densities of 0 . quadrata in the estuarine beaches were similar to those observed in the oceanic beaches. However, the absence of burrows at the four innermost beaches suggests that low salinity and sediment penetrability may prevent ghost crabs from occurring in this region of the estuary. Burrow densities showed strong seasonal variability. The low densities observed during the winter are probably related to a delay crab activities due to low temperatures in the early morning during this season. The absence of a clear zonation pattern was related to estuarine beach morphology.
\end{abstract}

KEY WORDS. Estuarine sandy beaches; low-energy environments; management and conservation; salinity; zonation.

RESUMO. Distribuição espacial de Ocypode quadrata (Crustacea: Ocypodidae) ao longo de ambientes estuarinos no sul do Brasil. O presente estudo avalia a distribuição espacial de Ocypode quadrata Fabricius, 1787 em treze praias estuarinas distribuídas ao longo dos dois principais eixos do complexo estuarino da Baia de Paranaguá, sul do Brasil. Em cada praia, a densidade de tocas do caranguejo em três níveis distribuídos em torno da marca da preamar foi estimada durante os períodos de verão e de inverno. Todas as praias apresentaram uma declividade bem acentuada $\left(2,6\right.$ a $8,3^{\circ}$ de inclinação) e a composição do sedimento variando, em direção ao interior do estuário, de areia fina bem selecionada a areia grossa muito pobremente selecionada. A salinidade da água variou entre 31 (próximo à desembocadura da baía) e 14 nas praias estuarinas mais internas. As densidades de tocas de 0 . quadrata nas praias estuarinas foram similares às registradas para as praias oceânicas. Entretanto, a ausência de tocas nas quatro praias estuarinas mais internas sugere que a salinidade junto com a penetrabilidade do sedimento possam ser fatores que inibam a ocorrência desse caranguejo nas regiões superiores do estuário. Entre as outras praias, a densidade de tocas mostrou uma marcada sazonalidade; os baixos valores observados durante o inverno estão provavelmente relacionados a um atraso na atividade dos caranguejos devido às baixas temperaturas durante o começo das manhãs de inverno. A ausência de um claro padrão de zonação foi relacionada à particular morfologia das praias estuarinas.

PALAVRAS-CHAVE.Ambientes de baixa energia; conservação e manejo; praias arenosas estuarinas; salinidade; zonação.

Ghost crabs, species of Ocypode Fabricius, 1798, are the most widespread members of Ocypodidae, being commonly found in tropical and subtropical sandy beaches around the world (McLachlan \& Brown 2006). Only one species, Ocypode quadrata (Fabricius, 1787), represents this genus in the Brazilian coast, where it builds semi-permanent burrows, mainly from the upper intertidal to the fore dunes of oceanic beaches (Melo 1996, Alberto \& Fontoura 1999).
Because the estimation of population density by counting the number of ghost crab burrows is a very simple and rapid technique (WARREN 1990), species of Ocypode have been frequently used as bioindicators of urbanization in high-energy oceanic sandy beaches worldwide (Fisher \& Tevesz 1979, Steiner \& Leatherman 1981, Barros 2001, Blankensteyn 2006, Neves $\&$ Bemvenuti 2006). However, the behavior of ghost crabs is very complex and flexible (BARRASS 1963), and differences in habitat 


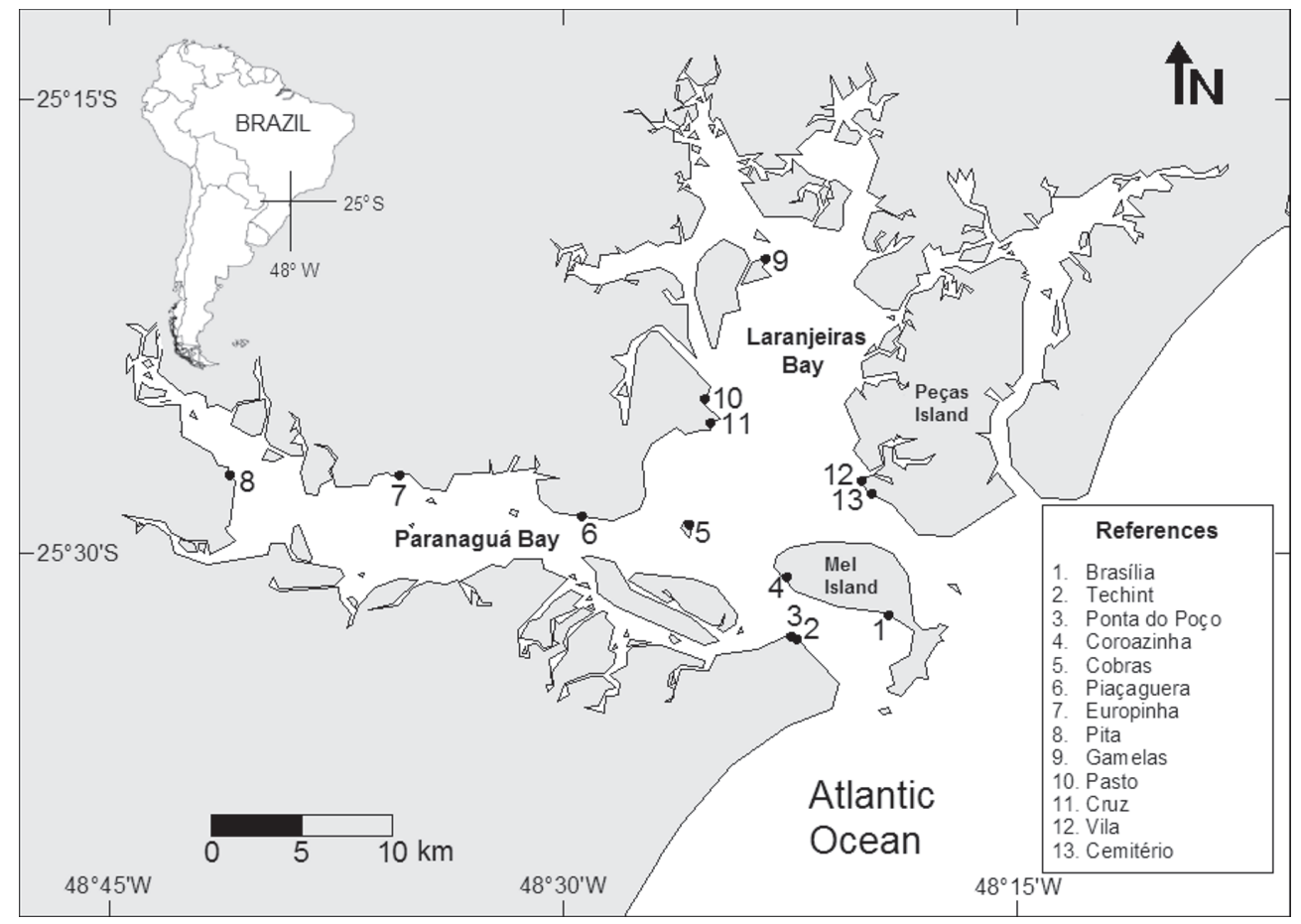

Figure 1. Sand beach sampled at Paranaguá Bay Estuarine Complex.

and/or diet (Jones 1972) can affect their activity (HugHes 1966). Therefore, knowledge of the behavior of natural population at a particular environment should be considered before the species could be used as a bioindicator of conservation status.

Previous studies of Brazilian populations of ghost crabs were based on the reproductive cycle and recruitment (NegreIROS-FrAnsozo et al. 2002) and spatial distribution in a southern high-energy oceanic sandy beach (AlBERTo \& FonToura 1999) and in low-energy tide-dominated sandy beaches (TurRa et al. 2005). In the latter, anthropogenic impact on ghost crab density may be confounded by natural response to high environmental heterogeneity that are characteristic of low-energy sandy beaches.

The main objective of this study was to describe the spatial distribution and abundance of O. quadrata in low-energy sandy beaches with low anthropogenic influence in the estuarine complex of Paranaguá Bay (southern Brazil) and to evaluate which environmental factors could affect its distribution along this estuarine system.

\section{MATERIAL AND METHODS}

\section{Study area}

The estuarine complex of Paranaguá Bay (Fig. 1) comprises two main water bodies, the Paranaguá bay (extended east to west) and the Laranjeiras bay (extended north to south); both bays open to the ocean through two tidal channels around the Mel Island. This estuarine system has been classified as a partially mixed estuary (type B) (KNoppers et al. 1987). Circulatory patterns and stratification vary between seasons and mean salinity range from 12 to 29 in the summer and from 20 to 34 in the winter. A complete characterization of the Paranaguá Bay Estuarine Complex may be found in Lana et al. (2001).

\section{Sampling and data analysis}

This study was conducted in thirteen estuarine beaches, distributed along the two main axes of the estuarine complex (i.e., Paranaguá and Laranjeiras bay, Fig. 1). Samplings were performed once at each season. All beaches were sampled once in the summer (Feb-Mar) and once during the winter (AugSept) of 2005 (early morning during low spring tide). In each beach, the number of active burrows was recorded in 10 contiguous quadrats $\left(1 \mathrm{~m}^{2}\right)$, aligned parallel to the shore, and at three equidistant levels distributed around the high spring tidal mark (Fig. 2). These three levels were selected based on the spatial distribution of crab burrows on the beaches.

During each survey, beach-face slope and water salinity were measured at each locality. Sediment samples $(n=3)$ were also collected at each level for granulometric and humidity analysis. Samples were dried at $60{ }^{\circ} \mathrm{C}$ for $48 \mathrm{~h}$ to determine moisture content through weight loss. Mean grain size and sorting were obtained by sieving dried samples following Suguio (1973), for methodology, and WENTwORTH (1922), for grain size scale.

A hierarchical analysis of variance (UNDERWOOD 1997) was used to test for differences in number of burrows between sea- 
Terrestrial vegetation

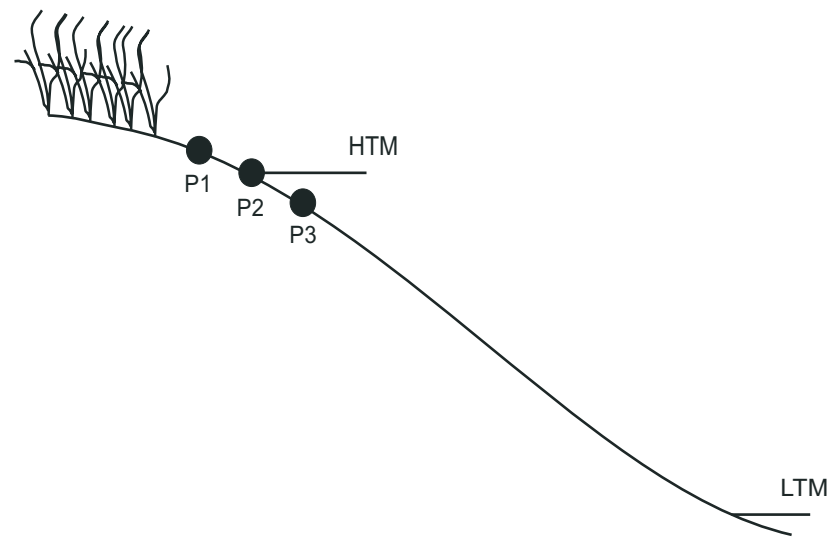

Figure 2. Schematic diagram of the three levels sampled at each beach. (P1) Supralittoral, (P2) drift line, (P3) upper intertidal, (HTM) high tide mark, (LTM) low tide mark. son, beaches within seasons and levels within beaches. All data were square-root transformed and found to be homogeneous at $\mathrm{p}>0.05$ using Cochran's C-test (UNDERWood 1997). Multiple comparisons among the means were done using the StudentNewman-Keuls (SNK) test.

The relationship between total burrow abundance and abiotic variables (beach face slope, grain size and sorting, moisture content and water salinity) was determined by the Spearman rank correlation.

\section{RESULTS}

All beaches showed a steep-beach face slope ranging from 2.6 (Cemitério beach, winter period) to $8.3^{\circ}$ (Pasto beach, winter period). Sediment composition varied from well-sorted fine sand to very poorly sorted coarse sand. An increase in grain size as well as a decrease in sorting coefficient was observed upward in the estuary (Tab. I). Sediment moisture content varied from 2.3 (Europinha, winter period) to $18 \%$ (Cemitério, summer pe-

Table I. Abiotic parameters measured in each beach during summer and winter surveys. Sediments parameters are referred as mean ( \pm standard deviation) of three beach levels. $\left(^{*}\right)$ Indicates beaches without burrows.

\begin{tabular}{|c|c|c|c|c|c|c|}
\hline Beach & Season & Beach slope $\left(^{\circ}\right)$ & Salinity & Grain size $(\phi)$ & Sorting $(\phi)$ & Moisture (\%) \\
\hline \multirow[t]{2}{*}{ Brasília } & Summer & 4.6 & 29 & $2.1( \pm 0.8)$ & $0.5( \pm 0.2)$ & $6.5( \pm 2.3)$ \\
\hline & Winter & 3.8 & 30 & $2.5( \pm 0.0)$ & $0.3( \pm 0.0)$ & $10.3( \pm 5.6)$ \\
\hline \multirow[t]{2}{*}{ Techint } & Summer & 4.0 & 30 & $2.3( \pm 0.3)$ & $0.6( \pm 0.4)$ & $11.0( \pm 7.4)$ \\
\hline & Winter & 4.5 & 30 & $2.6( \pm 0.1)$ & $0.3( \pm 0.0)$ & $8.0( \pm 5.9)$ \\
\hline \multirow[t]{2}{*}{ Ponta do Poço } & Summer & 6.3 & 30 & $2.6( \pm 0.0)$ & $0.3( \pm 0.0)$ & $9.6( \pm 4.5)$ \\
\hline & Winter & 5.5 & 31 & $2.7( \pm 0.0)$ & $0.3( \pm 0.1)$ & $8.8( \pm 5.6)$ \\
\hline \multirow[t]{2}{*}{ Coroazinha } & Summer & 5.0 & 28 & $2.3( \pm 0.1)$ & $0.3( \pm 0.0)$ & $10.7( \pm 8.3)$ \\
\hline & Winter & 3.7 & 30 & $2.3( \pm 0.3)$ & $0.4( \pm 0.0)$ & $14.2( \pm 2.4)$ \\
\hline \multirow[t]{2}{*}{ Cobras } & Summer & 7.3 & 30 & $1.4( \pm 0.0)$ & $0.6( \pm 0.0)$ & $4.1( \pm 3.4)$ \\
\hline & Winter & 6.4 & 30 & $1.2( \pm 0.3)$ & $0.4( \pm 0.1)$ & $8.1( \pm 4.4)$ \\
\hline \multirow[t]{2}{*}{ Piaçaguera * } & Summer & 4.4 & 21 & $2.5( \pm 0.0)$ & $0.3( \pm 0.0)$ & $12.4( \pm 2.3)$ \\
\hline & Winter & 5.2 & 21 & $1.9( \pm 0.3)$ & $0.3( \pm 0.0)$ & $10.2( \pm 5.1)$ \\
\hline \multirow[t]{2}{*}{ Europinha * } & Summer & 5.1 & 16 & $0.4( \pm 0.0)$ & $1.1( \pm 0.0)$ & $2.8( \pm 1.0)$ \\
\hline & Winter & 5.7 & 19 & $0.5( \pm 0.2)$ & $1.1( \pm 0.1)$ & $3.4( \pm 0.5)$ \\
\hline \multirow[t]{2}{*}{ Pita * } & Summer & 5.9 & 14 & $1.0( \pm 0.3)$ & $1.2( \pm 0.1)$ & $7.1( \pm 2.4)$ \\
\hline & Winter & 7.2 & 15 & $0.4( \pm 0.1)$ & $1.0( \pm 0.0)$ & $2.3( \pm 1.2)$ \\
\hline \multirow[t]{2}{*}{ Cemitério } & Summer & 3.6 & 26 & $2.7( \pm 0.0)$ & $0.4( \pm 0.0)$ & $18.0( \pm 0.5)$ \\
\hline & Winter & 2.6 & 32 & $2.6( \pm 0.0)$ & $0.3( \pm 0.0)$ & $17.8( \pm 0.1)$ \\
\hline \multirow[t]{2}{*}{ Vila } & Summer & 5.4 & 25 & $2.6( \pm 0.0)$ & $0.3( \pm 0.0)$ & $5.9( \pm 2.6)$ \\
\hline & Winter & 3.0 & 32 & $2.6( \pm 0.1)$ & $0.3( \pm 0.0)$ & $13.5( \pm 3.1)$ \\
\hline \multirow[t]{2}{*}{ Cruz } & Summer & 6.2 & 24 & $2.1( \pm 0.2)$ & $0.6( \pm 0.1)$ & $5.1( \pm 0.9)$ \\
\hline & Winter & 6.8 & 30 & $2.1( \pm 0.4)$ & $0.7( \pm 0.1)$ & $5.6( \pm 1.7)$ \\
\hline \multirow[t]{2}{*}{ Pasto } & Summer & 6.5 & 25 & $2.1( \pm 0.6)$ & $0.4( \pm 0.1)$ & $5.1( \pm 2.4)$ \\
\hline & Winter & 8.3 & 30 & $2.0( \pm 0.4)$ & $0.5( \pm 0.0)$ & $4.7( \pm 2.6)$ \\
\hline \multirow[t]{2}{*}{ Gamelas * } & Summer & 6.5 & 20 & $1.9( \pm 0.2)$ & $0.6( \pm 0.2)$ & $10.0( \pm 2.4)$ \\
\hline & Winter & 6.4 & 30 & $1.5( \pm 0.2)$ & $0.7( \pm 0.1)$ & $5.4( \pm 4.2)$ \\
\hline
\end{tabular}


riod). Water salinity ranged from around 31, at beaches near the bay inlet, to 14 at beaches in the inner estuary. Mean values of all abiotic parameters are presented in table I.

Ghost crab burrows were not found at Piaçaguera, Europinha, Pita, and Gamelas, all situated in the most inner portion of the estuary (Fig. 1). In the remaining beaches, total abundance ranged from 10 (Techint) to 62 burrows (Coroazinha), and from two (Techint and Coroazinha) to seven burrows (Cemitério), during summer and winter surveys, respectively (Tab. II). Statistical analyses showed significant differences in burrow density for all evaluated factors (Tab. III). Burrow densities ranged from 0.0 to 5.7 burrows $/ \mathrm{m}^{2}$ and from 0.0 to 0.4 burrows $/ \mathrm{m}^{2}$, during summer and winter surveys, respectively (Figs 3-4). Seasonal differences in burrow densities were only observed at Coroazinha, Brasília, Pasto, and Cobras beaches, with the highest densities recorded in the summer. Higher densities of burrows were observed at the upper levels of Coroazinha and Brasília beaches during the summer (Figs 34). During the winter, burrow densities were not significantly different among beaches or levels (Figs 3-4).
Table III. Summary of the hierarchical analyses of variance evaluating differences in burrows densities of Ocypode quadrata among season periods, beaches and beach levels.

\begin{tabular}{lrrrr}
\hline Source of variation & $\mathrm{df}$ & \multicolumn{1}{c}{ MS } & \multicolumn{1}{c}{$\mathrm{F}$} & $\mathrm{p}$ \\
\hline Season & 1 & 27.29 & 132.46 & $<0.001$ \\
Beach(Season) & 16 & 1.31 & 6.33 & $<0.001$ \\
Level(Beach(Season)) & 36 & 1.48 & 7.19 & $<0.001$ \\
Error & 540 & 0.21 & & \\
\hline
\end{tabular}

Due to the low burrow densities in the winter, a Spearman correlation was conducted using summer data only. Densities of crab burrows showed a significant and positive relationship with grain size (grain size in $\phi ; R=0.60, p=0.03$ ) and water salinity $(\mathrm{R}=0.72, \mathrm{p}=0.01)$.

\section{DISCUSSION}

Current studies on $O$. quadrata are restricted to populations from open oceanic beaches, which generally have a large and gentle beach face. In contrast to these environments, es-

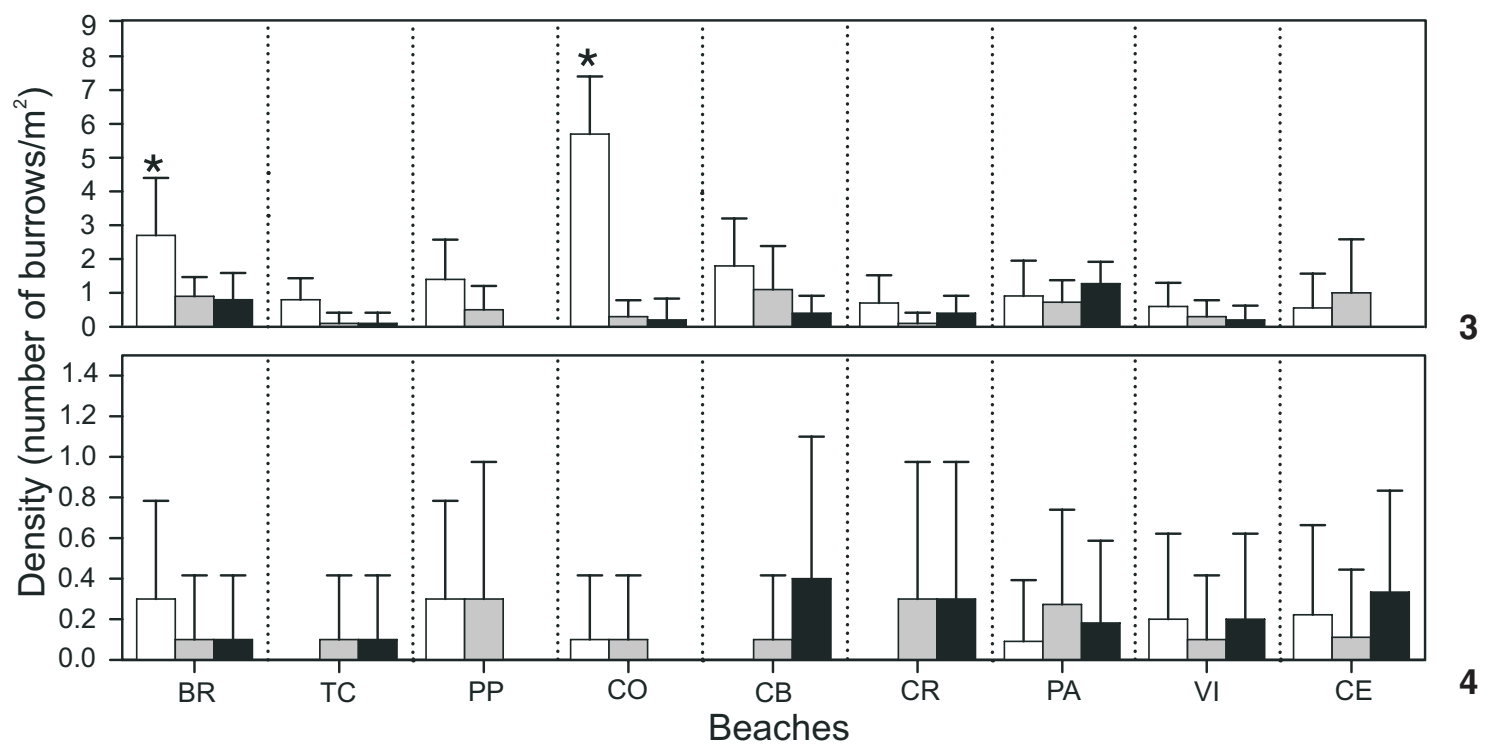

Figures 3-4. Mean (+1 SD) densities of the Ocypode quadrata burrows at each level (P1: white columns, P2: gray columns and P3: black columns) on the beaches of the bay during summer (3) and winter (4) surveys. Asterisks designate significant differences for burrow densities among beach levels within the beach. (BR) Brasília, (TC) Techint, (PP) Ponta do Poço, (CO) Coroazinha, (CB) Cobras, (CE) Cemitério, (VI) Vila, (CR) Cruz, (PA) Pasto.

Table II. Total burrows abundance of the Ocypode quadrata registered at each beach during summer and winter of 2005.

\begin{tabular}{lccccccccc}
\hline \multirow{2}{*}{ Season } & \multicolumn{10}{c}{ Beaches } \\
\cline { 2 - 11 } & Brasilia & Techint & P. Poço & Coroazinha & Cobras & Cemitério & Vila & Cruz & Pasto \\
\hline Summer & 44 & 10 & 19 & 62 & 33 & 14 & 11 & 12 & 32 \\
Winter & 5 & 2 & 6 & 2 & 5 & 7 & 4 & 6 & 6 \\
\hline
\end{tabular}


tuarine beaches are characterized by narrow and steep beach face (Nordstron 1992, Borzone et al. 2003). However, regardless of reduction of the available habitat, our results showed that burrow densities of O. quadrata in estuarine beaches of Paranaguá Bay are similar or greater that those found in species at oceanic beaches (Tab. IV).

Table IV. Densities values (burrows $/ \mathrm{m}^{2}$ ) of Ocypode quadrata burrow registered at this study and at others oceanic sandy beaches.

\begin{tabular}{|c|c|c|}
\hline Range density & Region & Source \\
\hline $0.0-5.7$ (summer) & Paranaguá Bay, Brazil & This study \\
\hline $0.0-0.4$ (winter) & Paranaguá Bay, Brazil & This study \\
\hline $0.002-0.24$ & $\begin{array}{l}\text { Rio Grande do Sul, } \\
\text { Brazil }\end{array}$ & $\begin{array}{l}\text { ALBERTO \& FONTOURA } \\
\text { (1999) }\end{array}$ \\
\hline $0.3-5.0$ & $\begin{array}{l}\text { Rio Grande do Sul, } \\
\text { Brazil }\end{array}$ & $\begin{array}{l}\text { Neves \& Bemvenuti } \\
(2006)\end{array}$ \\
\hline $0.0-2.13$ & Santa Catarina, Brazil & BLANKENSTEYN (2006) \\
\hline $0.0-2.85$ & São Paulo, Brazil & TURRA et al. (2005) \\
\hline $0.005-0.014$ & North Caroline, USA & $\begin{array}{l}\text { WolCOTT \& WolCOT } \\
\text { (1984) }\end{array}$ \\
\hline $0.49-1.79$ & Veracruz, Mexico & $\begin{array}{l}\text { VALERO-PACHECO et al. } \\
(2007)\end{array}$ \\
\hline
\end{tabular}

For most estuarine beaches, lower burrow densities were observed during winter compared to summer sampling. This is probably related to seasonal differences of ghost crab rhythms, with low activities during cold days as already recorded for $O$. quadrata in other beaches (Haley 1969, Leber 1981, Alberto \& FonTOURA 1999).

Ghost crab activity is most strongly influenced by temperature, with $16^{\circ} \mathrm{C}$ being the lower limit for normal activities (Haley 1969, Leber 1981, Alberto \& Fontoura 1999). When temperature drops below this limit, O. quadrata remains confined to the burrow and becomes active as soon as temperatures increase a few degrees (Haley 1969). During adverse conditions, such as intense winds and sea storms, ghost crabs take shelter in their burrows and close the openings with sand, and may, also, stay inactive for long periods of time. Consequently, seasonality of the environmental conditions can also result in different dial activities rhythms, with crabs being active later in the day during winter periods. These seasonal differences in dial activity rhythms were observed in a subtropical population of O. quadrata (Alberto \& Fontoura 1999). In this study, higher numbers of emerging crabs were observed close to midday during winter conditions, whereas the activity peak occurs close to sunset during summer days.

Field observations in one of the studied estuarine beaches showed a marked seasonality on the dial variation of sediment temperature (personal observations). During the winter season, the temperature varied from 15 to $21^{\circ} \mathrm{C}$ between 8:00 and
11:00 $\mathrm{AM}$, but the temperature remained above $27^{\circ} \mathrm{C}$ during the same period in the summer.

Observed seasonal differences in burrow densities could be related to differences in the onset of activity of the ghost crabs since all surveys were conducted at the same time (early in the morning). This hypothesis is currently being investigated by evaluating the dial rhythm of the crab activity in one of the sampled estuarine beach. Burrows were exclusively distributed along the three sampled levels, with a supratidal preference (level P1) in only two beaches, which presented the highest abundance (Coroazinha and Brasília). In contrast to large exposed oceanic beaches, estuarine beaches are characterized by a narrow and steep beach face, usually without berm formation, and with more compact sediment (NORDSTRON 1992, Borzone et al. 2003). In addition, the supratidal zone is restricted to a narrow band (a few meters) and can also be easily covered by the tide during storm surges and intense winds.

The correlation between burrow density, water salinity, and sediment grain size suggests that low salinities and coarse sediment, together with the lack of a berm facilitating gallery constructions, could be factors limiting the distribution of $O$. quadrata towards the upper estuary at the Paranaguá estuarine complex. Even though species of Ocypode can tolerate a wide range of salinities (WoLcotT 1988), low salinities may prevent the occurrence of these species in the upper estuarine regions (Ewа-Овоно 1993). In addition, little or no information is available about the relationship between gallery construction and textural sediment characteristics for species of this genus.

Estuarine beaches can provide suitable habitats for $O$. quadrata populations in spite of its short and more heterogeneous environment compared to ocean counterparts. Consequently, these crabs may indeed be used as an indicator of human interference on sandy beaches along estuarine environments in the future. Furthermore, salinity and sediment characteristics should be considered as important physical variables limiting the distribution of ghost crabs, particularly at the upper estuary.

\section{ACKNOWLEDGEMENTS}

The authors would like to thank Veronica Manrique from University of Florida, USA, for her critical language corrections of a previous version of this manuscript. We also thank the anonymous referees for their helpful comments.

\section{LITERATURE CITED}

Alberto, R.M.F. \& N.F. Fontoura. 1999. Distribuição e estrutura etária de Ocypode quadrata (Fabricius, 1787) (Crustacea, Decapoda, Ocypodidae) em praia arenosa do litoral sul do Brasil. Revista Brasileira de Biologia 59: 95-108.

BARrass, R. 1963. The burrows of Ocypode ceratophalmus (Pallas) (Crustacea, Ocypodidae) on a tidal wave beach at Inhaca Island, Moçambique. Journal of Animal Ecology 32: 73-85. 
Barros, F. 2001. Ghost crabs as a tool for rapid assessment of human impacts on exposed sandy beaches. Biological Conservation 97: 399-404.

Blankensteyn, A. 2006. O uso do caranguejo maria-farinha Ocypode quadrata (Fabricius) (Crustacea, Ocypodidae) como indicador de impactos antropogênicos em praias arenosas da Ilha de Santa Catarina, Santa Catarina, Brasil. Revista Brasileira de Zoologia 23: 870-876.

Borzone, C.A.; S.G. Melo; K.V. Rezende; R. Vale \& R. Krul. 2003. Macrobenthic intertidal communities from wave to tide dominated beach environments. A case study in two Brazilian beaches. Journal of Coastal Research SI35: 472480.

Еша-Овоно, I.O. 1993. Substratum preference of the tropical estuarine crabs, Uca tangeri Eydoux (Ocypodidae) and Ocypode cursor Linne (Ocypodidae). Hydrobiologia 271: 119-127.

Fisher, J.B. \& M.J.S. Tevesz. 1979. Within-habitat spatial patterns of Ocypode quadrata (Fabricius) (Decapoda, Brachyura). Crustaceana 5: 31-36.

Haley, S.R. 1969. Relative growth and sexual maturity of the Texas ghost crab, Ocypode quadrata (Fabricius) (Brachyura, Ocypodidae). Crustaceana 17: 285-297.

Hughes, D.A. 1966. Behavioral and ecological investigations of the crab Ocypode ceratophthalmus (Crustacea: Ocypodidae). Journal of Zoology 150: 129-143.

Jackson, L.F.; M.J. Smale \& P.F. Berry. 1991. Ghost crabs of the genus Ocypode (Decapoda, Brachyura, Ocypodidae) of the east coast of South Africa. Crustaceana 61: 280-286.

Jones, D.A. 1972. Aspects of the ecology and behavior of Ocypode ceratophalmus (Pallas) and O. Kuhlii de Haan (Crustacea: Ocypodidae). Journal of Experimental Marine Biology and Ecology 8: 31-43

Knoppers, B.A.; F.P. Brandini \& C.A. Thamm. 1987. Ecological studies in the Bay of Paranaguá. II- Some physical and chemical chacteristics. Nerítica 2: 1-36.

Lana, P.C.; E. Morone; R.M. Lopes \& E.C. Machado. 2001. The Subtropical Estuarine Complex of Paranaguá Bay, Brazil, p. 131-145. In: U. Seeliger \& B. Kjerfve (Eds). Coastal Marine Ecosystems of Latin America. Berlin, Springer-Verlag, $\mathrm{XX}+360 \mathrm{p}$.

LEBER, K.M. 1981. Spatial patterns of Ocypode quadrata: a reevaluation (Decapoda: Brachyura). Crustaceana 41: 110-112.
Mclachlan, A. \& A. BRown. 2006. The ecology of sandy shores. San Diego, Academic Press, XII+373p.

Melo, G.A.S. 1996. Manual de identificação dos Brachyura (caranguejos e siris) do litoral brasileiro. São Paulo, Ed. Plêiade, $\mathrm{X}+603 \mathrm{p}$.

Negreiros-Fransozo, M.L.; A. Fransozo \& G. Bertini. 2002. Reproductive cycle and recruitment period of Ocypode quadrata (Decapoda, Ocypodidae) at a sandy beach in southeastern Brazil. Journal of Crustacean Biology 22: 157-161.

Neves, F.M. \& C.E. Bemvenuti. 2006. The ghost crab Ocypode quadrata (Fabricius, 1787) as a potential indicator of anthropic impact along Rio Grande do Sul coast, Brazil. Biological Conservation 133: 432-435.

Nordstrom, K.F. 1992. Estuarine beaches. London, Elsevier Applied Science, 225p.

Steiner, A.J. \& S.P. Leatherman. 1981. Recreational impacts on the distribution of ghost crabs Ocypode quadrata Fab. Biological Conservation 20: 111-122.

Suguio, K. 1973. Introdução à sedimentologia. São Paulo, EDUSP, 317p.

Turra, A.; M.A.O. Gonçalves \& M.R. Denadai. 2005. Spatial distribution of the ghost crab Ocypode quadrata in low-energy tide-dominated sandy beaches. Journal of Natural History 39: 2163-2177.

UnderWOOD, A.J. 1997. Experiments in Ecology. Their logical design and interpretation using analysis of variance. Cambridge, Cambridge University Press, 504p.

Valero-Pacheco, E.; F. Alvarez; L. G. Abarca-Arenas \& M. Escobar. 2007. Population density and activity pattern of the ghost crab, Ocypode quadrata, in Veracruz, Mexico. Crustaceana 80: 313-325.

WARREN, J.H. 1990. The use of open burrows to estimate abundances of intertidal estuarine crabs. Australian Journal of Ecology 15: 277-280.

Wentworth, C.K. 1922. A scale of grade and terms for clastic sediments. Journal of Geology 30: 377-392.

Wolcott, T.G. 1988. Ecology, p. 55-96. In: W.W. Burggren \& B.R. McMahon (Eds). Biology of land crabs. New York, Cambridge University Press, XII+479p.

Wolcotт, T.G. \& D.L. Wolcotт. 1984. Impact of off-road vehicles on macroinvertebrates of a mid-atlantic beach. Biological Conservation 29: 217-240.

Submitted: 26.II.2008; Accepted: 02.IX.2008.

Editorial responsibility: Maria Lúcia Negreiros-Fransozo 